\title{
Population structure and seasonal movements of narwhals, Monodon monoceros, determined from mtDNA analysis
}

\author{
PER JAKOB PALSB $\varnothing L L^{*} \dagger$, MADS PETER HEIDE-JØRGENSEN $+\&$ RUNE DIETZ§ \\ $\dagger$ Department of Population Biology, Zoological Institute, University of Copenhagen, Universitetsparken 15, DK-2100 \\ Copenhagen $\emptyset$, $\ddagger$ Greenland Institute of Natural Resources, Tagensvej 135, 1, DK-2200 Copenhagen $N$ and \\ \$Department of Arctic Environment, National Environmental Research Institute, Tagensvej 135, 4, DK-2200 \\ Copenhagen N, Denmark
}

\begin{abstract}
We determined the nucleotide sequence of the first 287 base pairs in the mitochondrial control region from 74 narwhals, Monodon monoceros, collected in the North-west Atlantic. We detected four polymorphic sites that defined five haplotypes, two of which were found in single specimens. The same DNA sequence was characterized in an additional 353 specimens by digestion with two restriction endonucleases. In this manner each specimen could be assigned to one of the three most common haplotypes. The nucleotide diversity for the total sample (as well as the sequenced subset) was estimated as 0.0017 and pairwise genetic distances between haplotypes ranged from $0.0035-0.0070$. The low nucleotide diversity and the low average pairwise genetic distance between haplotypes suggest a recent expansion in abundance from a small founding population. Despite the low degree of variation, frequencies of the common haplotypes differed markedly between areas. The results indicate isolation, even between geographically close areas, as well as fidelity to specific summer and autumn feeding grounds. Heterogeneity within a presumed single breeding ground suggests mixing of pods with different haplotypic composition.
\end{abstract}

Keywords: Cetaceae, D-loop, evolution, low nucleotide diversity, Odontocetae, population genetics.

\section{Introduction}

The narwhal, Monodon monoceros, summers in open water areas of the High Arctic but spends the winter in close association with pack ice at lower latitudes (Hay \& Mansfield, 1989). Although narwhals appear to be well adapted to the High Arctic environment, the regular occurrence of 'sassat', the entrapment by ice and subsequent extinction of entire pods, demonstrates the unpredictability of this habitat (Siegstad \& Heide-Jørgensen, 1994).

\footnotetext{
*Correspondence: Department of Ecology and Evolutionary Biology, University of California, Irvine, CA 92717, U.S.A. E-mail: ppalsbol@newt.bio.uci.edu
}

Narwhals are usually encountered in pods composed of either mature females accompanied by calves and immature males or solely of mature males. The female pods are believed to be matrifocal and all mature females appear to reproduce. Mating is believed to occur once a year, in the spring or early summer on the wintering grounds (Hay \& Mansfield, 1989).

The current estimate of abundance for the combined Canadian and Greenland parts of Baffin Bay and adjacent waters is between 27600 and 42500 (IWC, 1992). No population estimates exist for eastern Greenland, but the relatively low number of catches and sightings in the area suggests a much smaller population relative to that of Baffin Bay (Dietz et al., 1994). 
Our present limited knowledge concerning patterns of annual migration and population structure in this species comes mainly from hunting records. The seasonal timing of catches indicates that West Greenland narwhals spend the summer in the high-latitude Avanersuaq district, then migrate southwards during the autumn (where they are hunted in the districts of Upernavik and Uummannaq) to winter in Disko Bay (Fig. 1). However, narwhals have also been observed offshore in the heavy pack ice in the Davis Strait as well as in central Baffin Bay (Koski \& Davis, 1994). In East Greenland narwhals are observed along most of the outer coast north of $64^{\circ} \mathrm{N}$ (Dietz et al., 1994). The paucity in sightings of narwhals as well as the lack of recordings of trade with tusks, meat or mattak (skin) south of Sisimiut $\left(66^{\circ} \mathrm{N}\right)$ suggests that no migration occurs between East and West Greenland (IWC, 1992; Reeves \& Heide-Jørgensen, 1994). Recently, satellite-linked radio transmitters have been employed to map the movements of narwhals in West Greenland. During the summers of 1993 and 1994 nine narwhals captured in Melville Bay were instrumented with satellite transmitters (Dietz \& Heide-Jørgensen, 1995). Two of the transmitters were monitored for 100 days. In both instances the instrumented narwhals migrated south along the western coast of Greenland, following the 1000 metre depth curve and wintered in the pack ice midway between Canada and Greenland. Thus the

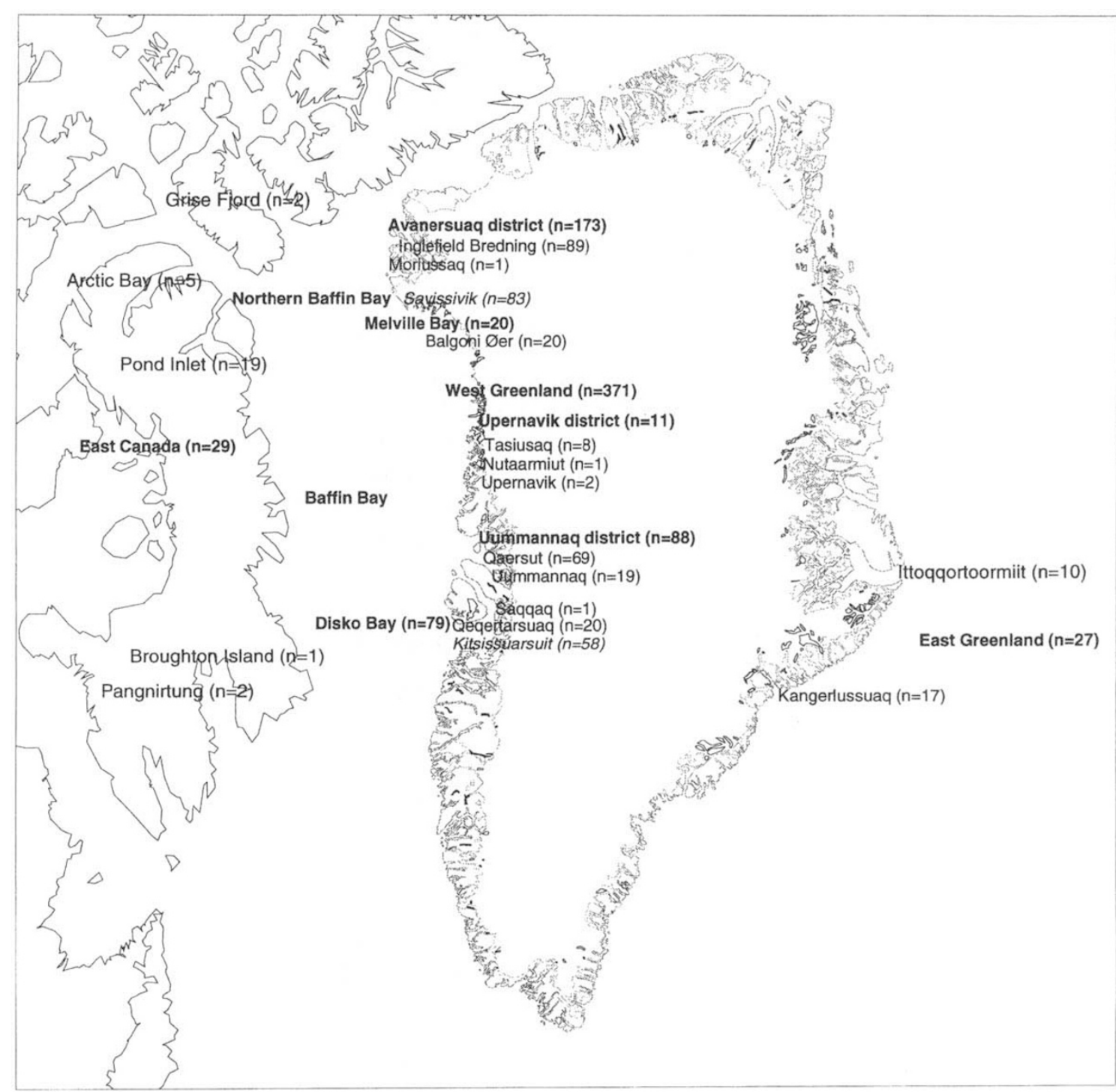

Fig. 1 Map of narwhal sampling localities. Localities in italics are where samples were obtained from sassats (see text). 
migration pattern observed from the instrumented narwhals confirmed the impression from the hunting records, as well as providing additional information from areas where no hunting takes place.

Here we present the results of a population genetic study based upon analysis of the first 287 nucleotides in the mitochondrial $(\mathrm{mt})$ control region. We analysed 427 narwhal samples obtained from summer, autumn and winter grounds in eastern and western Greenland as well as eastern Canada. The $\mathrm{mt}$ genome has previously been successfully applied as a genetic marker in studies of population structure in cetacean populations (Schaeff et al., 1991; Baker et al., 1993; Palsbøll et al., 1995). The maternal mode of inheritance and lack of recombination in this genome is an additional advantage for population studies of species (as is the case for many cetaceans) where site fidelity and/or pod structure are maternally directed.

\section{Methods}

\section{Sample collection and storage}

Samples of skin and muscle were collected by biologists or Inuit hunters during flensing of narwhals between 1984 and 1994, at the locations shown in Fig. 1. Samples were stored at $-28^{\circ} \mathrm{C}$ or in saturated sodium chloride with 20 per cent DMSO (dimethylsulphoxide) until analysis (Amos \& Hoelzel, 1991). From 1990 onwards, tissue samples were also collected from lower jaws supplied by the Inuit hunters. The jaws were frozen and mailed to the Greenland Institute of Natural Resources.

On two occasions (at Savissivik in February, 1994, and Kitsissuarsuit in March, 1994 - see Fig. 1), samples were collected from entire pods $(100-200$ individuals) which died in ice entrapments (HeideJørgensen, unpublished information). All other samples were collected from single narwhals taken from small $(n<20)$ pods.

\section{DNA extraction and analysis of the mt control region}

DNA was extracted using standard procedures by cell lysis with SDS (sodium dodecyl sulphate) followed by digestion with Proteinase $\mathrm{K}$ at $65^{\circ} \mathrm{C}$. Degraded proteins were removed by several phenol/ chloroform extractions and finally the nucleic acids were precipitated with ethanol (Maniatis et al., 1982). Single-stranded mtDNA for dideoxy sequencing (Sanger, 1981) was obtained by symmetric amplification and subsequent asymmetric amplification with AmpliTaq DNA polymerase (Gyllensten \& Erlich, 1988; Saiki et al., 1988). Symmetric amplifications of the whole $\mathrm{mt}$ control region were conducted with the primers MT3R and MT4F annealing to sequences flanking the mitochondrial control region in cetaceans (Arnason et al., 1993). Amplifications were performed in $20 \mu \mathrm{L}$ under the following conditions: $67 \mathrm{~mm}$ TrisCl, $\mathrm{pH} 8.8,2 \mathrm{mM} \mathrm{MgCl}_{2}, 16.6 \mathrm{~mm}$ $\left(\mathrm{NH}_{4}\right)_{2} \mathrm{SO}_{4}, 10 \mathrm{mM} \beta$-mercaptoethanol, $0.20 \mu \mathrm{M}$ per nucleotide), $1 \mu \mathrm{M}$ for each primer, 0.4 units AmpliTaq DNA polymerase and $\approx 10 \mathrm{ng}$ extracted genomic DNA. The temperature profile was: $1 \mathrm{~min}$ at $94^{\circ} \mathrm{C}, 1 \mathrm{~min}$ at $57^{\circ} \mathrm{C}$ and finally $3 \mathrm{~min} 30 \mathrm{~s}$ at $72^{\circ} \mathrm{C}$ for 28 cycles. Asymmetric amplifications were conducted with the primers MT4F and Mn312R (Arnason et al., 1993; Palsbøll et al., 1995). Amplifications were performed under similar conditions as the symmetric amplifications except that the reaction volume was $50 \mu \mathrm{L}$, the annealing temperature $55^{\circ} \mathrm{C}$ and the extension time $1 \mathrm{~min} 30 \mathrm{~s}$ for 30 cycles. All extractions and amplifications included blanks as controls for possible contamination. Sequencing was performed according to the manufacturer's instructions (Sequenase Ver. 2.0, US Biochemicals). The primers were MT4F, Mn312R and Mn152R (Palsbøll et al., 1995).

\section{Restriction endonuclease analysis}

Digestions of double-stranded PCR products with the endonucleases $M n l \mathrm{I}$ and $B g l \mathrm{II}$ were performed in $20 \mu \mathrm{L}$ volume under the conditions recommended by the manufacturer (New England Bio Labs). The restriction fragments were visualized by electrophoresis through 2 per cent $\mathrm{NuSieve}^{\mathrm{TM}}$ and staining with ethidium bromide.

\section{Sex determination}

The sex of each sample was determined using a PCR-based method (Bérubé \& Palsbøll, 1996).

\section{Data analysis}

The sample localities were divided into three main areas: eastern Greenland, western Greenland and northern Baffin Bay. Northern Baffin Bay includes eastern Canada and the Avernersuaq district. Although a total of 29 samples was collected in eastern Canada, only one locality (Pond Inlet) had a reasonable sample size of 19 specimens. For this reason only Pond Inlet samples were used in the homogeneity tests as representing eastern Canada. Western Greenland includes the localities Balgoni 


\begin{tabular}{|c|c|c|c|c|c|c|}
\hline & 1 & 11 & 21 & 31 & 41 & 51 \\
\hline \multirow{3}{*}{$\begin{array}{l}\text { D.delphis } \\
\text { M.monoceros }\end{array}$} & AAAAA-GCTT & ATTGTACAAT & TACCACAACA & TCACAGTACT & ACGTCAGTAT & TAAAAGTAAT \\
\hline & .G..G.T. & ....... & .Т.А.С. & .T....G. & $\ldots \ldots \ldots$ & $\ldots . A-C$ \\
\hline & 61 & 71 & 81 & 91 & 101 & 111 \\
\hline \multirow{3}{*}{$\begin{array}{l}\text { D.delphis } \\
\text { M.monoceros }\end{array}$} & TTGTTTTAAA & AACATTTTAC & TGTACATATT & ACATACACAT & ACACATGTAC & ATGCTAATAT \\
\hline & C.A...C..T & $-\ldots \ldots \ldots$ & $\ldots$. GC... & G....T.GC & . T... СAC.. & G.CA...ATC \\
\hline & 121 & 131 & 141 & 151 & 161 & 171 \\
\hline \multirow{3}{*}{$\begin{array}{l}\text { D. delphis } \\
\text { M.monoceros }\end{array}$} & TTAGTCTСTC & CTTGTAAATA & TTCATATATT & CATGCTATGT & ATTATTGTGC & АTTCATTTAT \\
\hline & ...... & ........ &.$c \ldots \ldots$ & ....... & ........ & ........ \\
\hline & 181 & 191 & 201 & 211 & 221 & 231 \\
\hline \multirow{3}{*}{$\begin{array}{l}\text { D. delphis } \\
\text { M.monoceros }\end{array}$} & TTTCCATACG & ATAAGTTAAA & GCTCGTATTA & ATTATTATTA & ATTTTACATA & TTACATAATA \\
\hline & $\ldots \ldots \ldots$ & G.C..... & $\ldots \ldots \ldots$ & .A. . . . & $\ldots \ldots$... &.$c \ldots \ldots$ \\
\hline & 241 & 251 & 261 & 271 & 281 & \\
\hline D.delphis & TGCATCCTCT & TACATATTAT & АТАТССССТT & САATTTCATT & TCCATTATA & \\
\hline M.monoceros & ....G.... & . & ..G. . . A. & TC...T... & ....... & \\
\hline
\end{tabular}

Fig. 2 Alignment of the sequenced 287 nucleotides in Monodon monoceros with Delphinus delphis.

Øer (in the Melville Bay), Upernavik district, Uummannaq district and Disko Bay.

The nucleotide diversity was estimated as defined by Nei $(1987 ;$ p. 256). The degree of genetic isolation between partitions was estimated as $H_{\mathrm{ST}}$ (Hudson et al., 1992) and tested for statistical significance by comparison with 1000 Monte Carlo simulations (Hudson et al., 1992). Rare haplotypes were not lumped together (Roff \& Bentzen, 1992; Hudson, 1992). Samples were considered heterogeneous if a similar or more extreme value of $H_{\mathrm{ST}}$ was obtained in less than 5 per cent of the Monte Carlo simulations. The homogeneity tests were conducted in a hierarchical manner: males vs. females within each sampling locality; year to year; and neighbouring sampling localities. Partitions showing no significant degree of heterogeneity were pooled in subsequent tests.

\section{Results}

\section{Sequence analysis}

The complete nucleotide sequence of the first 287 base pairs of the $\mathrm{mt}$ control region was determined for 74 specimens. The consensus sequence, aligned with the homologous sequence in the common dolphin, Delphinus delphis (GeneBank accession no. Midddu017 (Rosel et al., 1994)), is shown in Fig. 2.

$\begin{array}{ccccc} & & 1 & 2 & 2 \\ & 5 & 1 & 3 & 6 \\ M m 001 & 8 & 7 & 2 & 5 \\ M m 002 & - & A & C & \mathrm{C} \\ \mathrm{Mm003} & \text { A } & . & \text {. } & \mathrm{T}^{1} \\ \mathrm{Mm004} & \text {. } & \text {. } & \mathrm{T} & \text { - } \\ \mathrm{Mm005} & \text {. } & \mathrm{G}^{2} & . & \text {. }\end{array}$

Fig. 3 Polymorphic sites in the observed haplotypes. Vertical numbers indicate the position relative to the consensus sequence in Fig. 2. A dash (-) symbolizes a deletion/insertion introduced to optimize alignment. 'Substitution creates a recognition site for the restriction endonuclease $\mathrm{Mnl} \mathrm{I}$. ${ }^{2}$ Substitution creates a recognition site for the restriction endonuclease BglII.

Only four polymorphic sites were detected, which defined five haplotypes (Fig. 3.). Apart from one insertion all polymorphisms were transitions. Of the 74 sequenced specimens all but seven had a sequence of either haplotype Mm001 or haplotype Mm002.

\section{Restriction analysis}

The 287 base-pair sequence was amplified in an additional 353 specimens and the product digested 
Table 1 The number of narwhal samples of each haplotype and gender from each sampling area

Mm001Mm002Mm003Mm004Mm005

\begin{tabular}{lrrrrr}
\hline $\begin{array}{l}\text { Eastern Canada } \\
\text { Females }\end{array}$ & 13 & 4 & - & 1 & 1 \\
Males & 9 & - & - & - & - \\
$\begin{array}{l}\text { Avanersuaq district } \\
\text { Females }\end{array}$ & 49 & 17 & 1 & - & 3 \\
Males & 71 & 26 & - & - & - \\
Melville Bay & & & & & \\
Females & 6 & 3 & - & - & - \\
Males & 3 & 8 & - & - & - \\
$\quad \begin{array}{l}\text { Upernavik district } \\
\text { Females }\end{array}$ & 1 & 1 & - & - & - \\
Males & 5 & 4 & - & - & - \\
Disko Bay & & & & & \\
Females & 7 & 7 & - & - & - \\
Males & 1 & 8 & - & - & - \\
Unknown gender & 5 & - & - & - & - \\
Disko Bay 1994 & & & & & \\
$\quad$ sassat & & & & & \\
Females & 18 & 5 & - & - & - \\
Males & 21 & 6 & - & - & 1 \\
$\begin{array}{l}\text { Uummannaq district } \\
\text { Females }\end{array}$ & & & & & \\
Males & 21 & 2 & - & - & - \\
Eastern Greenland & & 5 & - & - & - \\
Females & & & & & - \\
Males & - & 17 & - & - & - \\
\hline & - & 11 & - & - & - \\
\hline
\end{tabular}

with the restriction endonucleases $M n l \mathrm{I}$ and $B g l \mathrm{II}$. In this manner the $\mathrm{mt}$ control region of each specimen could be identified as either Mm002 or Mm003 (cut by $\mathrm{Mnl}$ I only), Mm005 (cut by $\mathrm{Bgl} \mathrm{II}$ ) or one of either Mm001 or $\mathrm{Mm004}$ (no restriction sites for either MnlI or BglII) (Fig. 3).

\section{Sex determination}

Sex was determined for 416 specimens (11 samples resisted proper amplification). Sex and $\mathrm{mt}$ control region haplotypes are summarized by year for the sample areas across years in Table 1 .

\section{Nucleotide and haplotype diversity}

The estimated nucleotide diversity for the 74 sequenced specimens was 0.0017 . The genetic distance between haplotypes varied from 0.0035 0.0070 . The estimated nucleotide diversity for all 427 specimens was also 0.0017 ignoring the haplotypes $\mathrm{Mm003}$ and $\mathrm{Mm004.}$

\section{Homogeneity tests}

No heterogeneity was detected between sexes in any area. Within the northern Baffin Bay (including the sassat samples from Savissivik in February, 1994) and eastern Greenland (monomorphic for haplotype Mm002) no heterogeneity was detected between years or sampling localities. In western Greenland, two instances of significant levels of heterogeneity were found: the samples from Uummannaq district differed in haplotype frequencies from the rest of the western Greenland sampling localities; and the samples originating from the sassat at Kitsissuarsuit in May 1994 differed from the Uummannaq samples as well as from the rest of the western Greenland samples, between which no significant levels of heterogeneity were detected. In summary, the homogeneity tests identified five 'entities': (i) northern Baffin Bay, (ii) eastern Greenland, (iii) Uummannaq district, (iv) the 1994 sassat at Kitsissuarsuit and (v) the remaining western Greenland localities (Melville Bay, Upernavik district \& Disko Bay, excepting the 1994 sassat samples). The $H_{\mathrm{ST}}$ values for these partitionings (along with the levels of significance) are listed in Table 2.

\section{Discussion}

\section{Low levels of nucleotide and haplotype diversity}

The current population of narwhals in the Baffin Bay region is relatively large when compared to many other cetacean species. Thus, it is surprising that the estimated nucleotide diversity is 0.0017 , which is one of the lowest values reported to date for any cetacean species (Table 3). Similar values have so far been observed only in cetacean populations which either number few animals (in the range of 300-500 individuals), and/or are assumed to have been founded recently by a few individuals (Table 3 ). The sequenced samples included specimens collected over a wide geographical range and time span (see Table 2). Hence the estimate of the nucleotide diversity is likely to be representative for the overall North-west Atlantic distribution of this species per se. Our findings resemble the results reported by Hoelzel et al. (1993) in a study of the northern elephant seal, Mirounga angustirostris, in which they reported an equally low nucleotide and haplotype diversity (two haplotypes with a genetic distance of 0.01 ). Today, northern elephant seals are 
Table 2 Results from homogeneity tests between narwhal samples ( $H_{\mathrm{ST}}$ values and level of significance)

\begin{tabular}{lcccccc}
\hline & $\begin{array}{c}\text { Eastern Canada \& } \\
\text { Avanersuaq district }\end{array}$ & Disko Bay & $\begin{array}{c}\text { Disko Bay 1994 } \\
\text { sassat }\end{array}$ & $\begin{array}{c}\text { Eastern } \\
\text { Greenland }\end{array}$ & $\begin{array}{c}\text { Melville Bay \& } \\
\text { Upernavik district }\end{array}$ & $\begin{array}{c}\text { Uummannaq } \\
\text { district }\end{array}$ \\
\hline Eastern Canada \& & - & $0.0166^{*}$ & NS & $0.24^{* * *}$ & $0.040^{* * *}$ & $0.038^{* * *}$ \\
Avanersuaq district & - & - & $0.046^{*}$ & $0.35^{* * *}$ & NS & $0.18^{* * *}$ \\
Disko Bay & & - & $0.53^{* * *}$ & $0.094^{* *}$ & $0.033^{*}$ \\
Disko Bay 1994 sassat & & & - & $0.27^{* * *}$ & $0.73^{* * *}$ \\
Eastern Greenland & & & & & - & $0.25^{* * *}$ \\
Melville Bay \& & & & & & - \\
Upernavik district & & & & & & - \\
Uummannaq district & & & & & &
\end{tabular}

${ }^{*} P<0.05 ;{ }^{* *} P<0.01 ;{ }^{* *} P<0.0001 ;$ NS, nonsignificant.

Table 3 Estimates of nucleotide diversity in other cetacean populations with low levels of genetic variation

\begin{tabular}{|c|c|c|c|}
\hline Species & Data & Nucleotide diversity & Source \\
\hline $\begin{array}{l}\text { †Stenella longirostris } \\
\text { Timor Sea } \\
\text { Eastern Pacific }\end{array}$ & $\begin{array}{l}\text { RFLP of total mt genome } \\
n=11 \\
n=79\end{array}$ & $\begin{array}{l}0.003 \\
0.012\end{array}$ & $\begin{array}{l}\text { Dizon et al. (1991) } \\
\text { Dizon et al. }(1991)\end{array}$ \\
\hline $\begin{array}{l}\text { Orcinus orca } \\
\text { North-eastern Pacific }\end{array}$ & $\begin{array}{l}\text { mt control region sequence } \\
n=8\end{array}$ & 0.002 & Hoelzel \& Dover (1991) \\
\hline $\begin{array}{l}\text { Eubalaena glacialis, } \\
\text { North Atlantic }\end{array}$ & $\begin{array}{l}\text { RFLP of total mt genome } \\
n=10\end{array}$ & 0.0026 & C. Schaeff, pers. comm. \\
\hline $\begin{array}{l}† \text { †egaptera novaeangliae } \\
\text { Hawaii } \\
\text { West Greenland }\end{array}$ & $\begin{array}{l}\text { mt control region sequence } \\
n=7 \\
n=44\end{array}$ & $\begin{array}{l}0.00 \\
0.026\end{array}$ & $\begin{array}{l}\text { Baker et al. }(1993) \\
\text { Palsbøll et al. }(1995)\end{array}$ \\
\hline
\end{tabular}

$\dagger$ For species where two estimates are given, the second estimate is an example of more commonly observed levels of nucleotide diversity within that particular species.

abundant $(\approx 120000$ individuals $)$, but the population underwent a severe bottleneck $(<30$ individuals) only a century ago because of intense hunting pressure.

Nothing is known concerning the past abundance of narwhals, but the data presented here strongly suggest that the current population was founded from only a few individuals relatively recently. The term 'recently' should be viewed in the proper context, which (taking the substitution rate into account) could be several tens of thousands years ago.

Such expansion could have been facilitated by the retreat of the ice after a glaciation and the consequent greater availability of habitat suitable for narwhals.
Another explanation which has been suggested to account for the low $\mathrm{mt}$ diversity, is the apparent matrifocal pod structure. Behavioural as well as genetic studies have demonstrated a matrifocal pod structure in several species of odontocetes (Amos et al., 1991, 1993; Duffield \& Wells, 1991). Hence, if a population is subdivided into several maternal pods, genetic drift will cause a reduction of the number of maternal lineages within each pod. The result will be a reduction (relative to a nonmatrifocal, panmictic population) in the nucleotide diversity (for mtDNA) within each pod. However, because each pod constitutes an independent maternal lineage it will diverge from maternal lineages (other pods) with time. Thus the effects of a matrifocal pod structure will not affect the nucleotide diversity at the population 
level, because different pods randomly become fixed for different haplotypes (especially in large populations such as that of the Baffin Bay region). Consequently, the matrifocal pod structure cannot explain the observed low nucleotide diversity across the entire geographical range included in this study. The cause proposed here, a rapid and recent expansion from a small founding population, seems the most plausible explanation for the unusually low level of diversity observed.

\section{Heterogeneous geographical distribution of $m t$ haplotypes}

Despite the low overall variation in the $\mathrm{mt}$ control region in the narwhal we still observed marked and significant differences in haplotype frequencies between sampling areas (Table 1).

\section{Eastern Greenland}

The fact that the eastern Greenland samples were monomorphic supports the hypothesis of little (or no) gene flow between eastern and western Greenland (IWC, 1992; Reeves \& Heide-Jørgensen, 1994).

\section{Summer grounds in the Baffin Bay region}

In the Baffin Bay region we analysed samples from summering grounds in eastern Canada, Avanersuaq district and Melville Bay. No significant levels of heterogeneity were found within the northern Baffin Bay (eastern Canada and Avanersuaq district) indicating some gene flow between summer grounds within this area. Furthermore, within the Avarnersuaq district, where samples were available from several years, haplotype frequencies appeared to be similar from year to year. Although the Melville Bay area is separated by only a few hundred kilometres from the Avanersuaq summer grounds, we found a significant level of heterogeneity between the northern Baffin Bay summer grounds and those of Melville Bay. Hence little gene flow is occurring between the western Greenland summer areas and northern Baffin Bay. However, it should be kept in mind that the sample size from Melville Bay $(n=20$ over two years) is quite low.

\section{Autumn and winter localities in the Baffin Bay region}

From the hunting records it is believed that narwhals summer in the northern Baffin Bay; migrate southward during the autumn; pass through the districts of Upenavik and Uummannaq, where they are hunted; and winter in Disko Bay and mid-Baffin Bay. The pairwise comparisons between sampling localities within the western Greenland area confirm the impression of an autumn southward migration along the coast to Disko Bay, but starting in the Melville Bay if we disregard the samples collected in Uummannaq district and from the sassat in the northern Disko Bay (Kitsissuarsuit) in 1994. The somewhat surprising finding that the narwhals taken in Uummannaq were heterogeneous when compared with those collected in Melville Bay and the Upernavik district, has been supported by recent satellite monitored trackings of narwhals (Dietz \& Heide-Jørgensen, 1995). Individual narwhals tracked by satellite in Melville Bay showed only limited movements within the summer area, hence confirming the findings from this study of little gene flow between northern Baffin Bay and Melville Bay. In the autumn the instrumented narwhals migrated southward following the 1000 metre depth curve. At the time when narwhals were observed and hunted in the Uummannaq district, the tagged narwhals had already arrived in their winter grounds, in the pack ice $200 \mathrm{~km}$ west of Disko Bay.

In Disko Bay sample sizes were generally small, except for the 58 samples collected from the sassat at Kitsissuarsuit in 1994. The sassat sample has haplotype frequencies which differ from all other partitionings apart from the northern Baffin Bay samples. The relatively rare haplotype Mm005 was found only in the northern Baffin Bay and the Disko Bay 1994 sassat samples. This could indicate that narwhal pods from different summer areas (in this case western Greenland and northern Baffin Bay) share the same breeding ground. That not all pods in the northern Baffin Bay area migrate southward and winter in the central Baffin and/or Disko Bays was demonstrated by the samples collected from the sassat at Savissivik (Avarnersuaq district) in February 1994. This sample had haplotype frequencies similar to the other localities within northern Baffin Bay.

In conclusion, the overall picture emerging from our analyses is consistent with the satellite trackings, and suggests an annual fidelity to relatively discrete summer and autumn feeding grounds. Our data suggest that pods of different genetic composition (summer feeding grounds?) utilize the same winter ground (here represented by Disko Bay). Maternally directed philopatry to separate summer feeding grounds (within a single breeding population) has been observed to affect the distribution of mtDNA haplotypes in other cetacean species (ex Palsbøll et 
al., 1995). Amos et al. (1993) have suggested (for pilot whales, Globicephala melaena) that pods may merge briefly during the mating season to facilitate outbreeding. The results presented here suggest that such a breeding system may also exist for narwhals.

\section{Acknowledgements}

We gratefully acknowledge the hunters in Greenland and Canada for providing samples from narwhals taken as part of the subsistence hunt and the Freshwater Institute of the Department of Fisheries and Oceans for forwarding the Canadian narwhal samples. We thank T. H. Andersen, C. FærchJensen, D. Poulsen and P. Raahauge for their dedicated effort in the laboratory. We also thank P. Clapham, H. R. Siegismund and R. R. Hudson for constructive comments on the manuscript and $\mathrm{H}$. R. Siegismund and R. R. Hudson for software. The study was in part funded by the Inuit Circumpolar Conference, and the Greenland Home Rule.

\section{References}

AMOS, W. AND HOELZEL, A. R. 1991. Long-term preservation of whale skin for DNA analysis. Rep. Int. Whaling Comm. Spec. Issue, 13, 99-104.

AMOS, B., BARRETT, J. AND DOVER, G. A. 1991. Breeding behaviour of pilot whales revealed by DNA fingerprinting. Heredity, 67, 49-55.

AMOS, B., SCHLÖTTERER, C. AND TAuTZ, D. 1993. Social structure of pilot whales revealed by analytical DNA profiling. Science, 260, 670-672.

ARNASON, U., GullberG, A. AND widegren, B. 1993. Cetacean mitochondrial DNA control region: Sequences of all extant baleen whales and two sperm whale species. Mol. Biol. Evol., 10, 960-970.

BAKER, C. S., PERRY, A., BANNISTER, J, L, WEINRICH, M. T., ABERNETHY, R. B., CALAMBODIKIS, J. ET AL. 1993. Abundant mitochondrial DNA variation and world-wide population structure in humpback whales. Proc. Natl. Acad. Sci., U.S.A., 90, 8239-8243.

BÉRUBÉ, M. AND PALSBØLL, P. J. 1996. Identification of sex in Cetaceans by multiplexing with three ZFX and ZFY specific primers. Mol. Ecol., 5, 283-287.

DIETZ, R. AND HEIDE-JøRGENSEN, M. P. 1995. Movements and swimming speed of narwhals (Monodon monoceros) instrumented with satellite transmitters in Melville Bay, Northwest Greenland. Can. J. Zool., 73, 2106-2119.

DIETZ, R., HEIDE-JøRGENSEN, M. P., BORN, E. W. AND GLAHDER, C. M. 1994. Occurrence of narwhals, Monodon monoceros, and white whales, Delphinapterus leucas, in East Greenland. Meddelelser om Grønland, Bioscience, 39, 69-86.

DIZON, A. E., SOUTHERN, S. O. AND PERRIN, W. F. 1991. Molecular analysis of mtDNA types in exploited popu- lations of Spinner dolphins (Stenella longirostris). Rep. Int. Whaling Comm. Spec. Issue, 13, 183-202.

DUFFIELD, D. A. AND WELLS, R. S. 1991. The combined application of chromosome, protein and molecular data for the investigation of social unit structure and dynamics in Tursiops truncatus. Rep. Int. Whaling Comm. Spec. Issue, 13, 155-170.

GYLLENSTEN, U. B. AND ERLICH, H. A. 1988. Generation of single-stranded DNA by the polymerase chain reaction and its application to direct sequencing of the HLA-DQA locus. Proc. Natl. Acad. Sci., U.S.A., 85, 7652-7656.

HAY, K. A. AND MANSFIELD, A. w. 1989. Narwhal Monodon monoceros Linnaeus, 1758 . In: Ridgeway, $\mathrm{H}$. and Harrison, R. (eds) River Dolphins and the Larger Toothed Whales. Handbook of Marine Mammals, vol. 4, pp. 145-176. Academic Press, London.

HOELZEL, A. R. AND DOVER, G. A. 1991. Genetic differentiation between sympatric killer whale populations. Heredity, 66, 191-195.

hOELZEL, A. R., HALleY, J., O'BRIEN, S. J., CAMPAGNA, C., ARNBOM, T., LE BOEUF, B. ET AL. 1993. Elephant seal genetic variation and the use of simulation models to investigate historical population bottlenecks. J. Hered., 84, 443-449.

HUDSON, R. R. 1992. Reply to Roff and Bentzen. Mol. Biol. Evol., 9, 969.

HUDSON, R. R., BOOS, D. D. AND KAPLAN, N. L. 1992. A statistical test for detecting geographic subdivision. Mol. Biol. Evol., 9, 138-151.

IWC 1992. Report of the sub-committee on small cetaceans. Rep. Int. Whaling Comm., 42, 178-234.

KOSKI, W. R. AND DAVIS, R. A., 1994. Distribution and numbers of narwhals (Monodon monoceros) in Baffin Bay and Davis Strait. Meddelelser om Grønland, Bioscience, 39, 15-40.

MANIATIS, T., FRITSCH, E. F. AND SAMBROOK, J. 1982. Molecular cloning. A Laboratory Manual. Cold Spring Harbor Laboratory, Cold Spring Harbor, NY.

NEl, M. 1987. Molecular Evolutionary Genetics. Columbia University Press, New York.

PALSBøll, P. J., Clapham, P. J., MATtila, D. K., LARSEN, F., SEARS, R., SIEGISMUND, H. R. ET AL. 1995. Distribution of mtDNA haplotypes in North Atlantic humpback whales: the influence of behaviour on population structure. Mar. Ecol. Progress Series, 116, 1-10.

REEVES, R. R. AND HEIDE-JøRGENSEN, M. P. 1994. Commercial aspects of narwhal exploitation in Greenland, with emphasis on the exportation of tusk ivory. Meddelelser om Grønland, Bioscience, 39, 119-134.

ROFF, D. E. AND BENTZEN, P. 1992. Detecting geographic subdivision: A comment on a paper by Hudson et al. Mol. Biol. Evol., 9, 968.

ROSEL, P. E., DIZON, A. E. AND HEYNING, J. E. 1994. Genetic analysis of sympatric morphotypes of common dolphins (genus Delphinus). Mar. Biol., 119, 159-167.

SAIKI, R. K., GELFAND, D. H., STOFFEl, S., SCHARF, S. J., HIGUCH, R., HORN, G. T. ET AL. 1988. Primer-directed enzymatic amplification of DNA with a thermostable 
DNA polymerase. Science, 239, 487-491.

SANGER, F. 1981. Determination of nucleotide sequences in DNA. Science, 214, 1205-1210.

SCHAEFF, C., KRAUS, S., BROWN, M., PERKINS, J., PAYNE, R., GASKIN, D., AND BOAG, P. 1991. Preliminary analysis of mitochondrial DNA variation within and between right whale species Eubalaena glacialis and Eubalaena australis. Rep. Int. Whaling Comm. Spec. Issue, 13, 155-170.

SIEGSTAD, H. AND HEIDE-JøRGENSEN, M. P. 1994. Ice entrapments of narwhals (Monodon monoceros) and white whales (Delphinapterus leucas) in Greenland. Meddelelser om Grønland, Bioscience, 39, 119-134. 